\title{
ANALISIS PENGARUH ONLINE SHOP TERHADAP PERILAKU KONSUMTIF PADA MAHASISWA FEB UMPRI (Studi Kasus Pada Mahasiswa Angkatan 2016)
}

\author{
Arohman $^{(1)}$, Nabila Cahya Vianda ${ }^{(2)}$ \\ Program Studi Manajemen, Fakultas Ekonomi dan Bisnis Universitas Muhammadiyah Pringsewu \\ Jl. KH. Ahmad Dahlan no.112 Pringsewu Lampung 35373 \\ Email : arohman@umpri.ac.id
}

\begin{abstract}
Abstrak
Perilaku konsumtif merupakan tindakan individu sebagai konsumen untuk membeli, menggunakan suatu barang atau jasa secara berlebihan, tidak rasional, menimbulkan pemborosan dan hanya mengutamakan keinginan atau kesenangan saja tanpa mempertimbangkan kebutuhan dan manfaat dari suatu barang atau jasa tersebut. Bahkan hanya untuk memperoleh pengakuan sosial, mengikuti tren atau kepuasan pribadi. Masalah dalam penelitian ini adalah perilaku konsumtif mahasiswa FEB UMPRI tinggi. Adapun rumusan masalah dalam penelitian ini adalah apakahonline shop berpengaruh terhadap perilaku konsumtif mahasiswa FEB UMPRI?. Tujuan penelitian ini adalah ingin mengetahui apakah Online Shop berpengaruh terhadap Perilaku Konsumtif mahasiswa FEB UMPRI . Penelitian ini menggunakan metode deskriptif kuantitatif dan pengumpulan data dalam penelitian ini menggunakan dokumentasi, observasi, dan kuesioner. Instrument penelitian menggunakan alat bantu berupa kuesioner dan diukur dengan skala likert. Populasi dalam penelitian ini adalah mahasiswa FEB UMPRI angkatan 2016 yang berjumlah 130 mahasiswa. Dengan sampel yang diambil sebanyak 26 mahasiswa FEB UMPRI angkatan 2016. Analisis data yang digunakan dalam penelitian ini adalah regresi linier sederhana.Berdasarkan hasil penghitungan dengan menggunakan analisis regresi linier sederhana, ternyata hipotesis yang diajukandapat diterima yaitu Online Shop berpengaruh terhadap Perilaku KonsumtifPada Mahasiswa Fakultas Ekonomi dan Bisnis Universitas Muhammadiyah Pringsewu Angakatan 2016.Hal ini dibuktikan dengan Nilai t-hitung Online Shop (X) sebesar 4,173>t-tabel $(0,684)$, dengan demikian $\mathrm{H}_{1}$ diterima dan $\mathrm{H}_{0}$ ditolak.Hasil perhitungan regresi linear Sederhana didapat nilai $r$-square sebesar 0,473 sehingga dapat disimpulkan bahwa Perilaku Konsumtifmahasiswa Fakultas Ekonomi dan Bisnis Universitas Muhammadiyah Pringsewu mampu dijelaskan sebesar 47,3\% oleh variabel Online Shop. Dengan kata lain, variabel Online Shop memberikan kontribusi sebesar 47,3\% terhadap Perilaku Konsumtif mahasiswa Fakultas Ekonomi dan Bisnis Universitas Muhammadiyah Pringsewu dan sisanya sebesar $52,7 \%$ dijelaskan atau dipengaruhi faktor lain yang tidak diidentifikasi dalam penelitian ini.
\end{abstract}

\section{Kata Kunci: Analisis Pengaruh Online Shop Terhadap Perilaku Konsumtif.}

\section{BAB I PENDAHULUAN}

\section{A. Latar Belakang}

Perilaku konsumtif merupakan tindakan individu sebagai konsumen untuk membeli, menggunakan suatu barang atau jasa secara berlebihan, tidak rasional, menimbulkan pemborosan dan hanya mengutamakan keinginan atau kesenangan saja tanpa mempertimbangkan kebutuhan dan manfaat dari suatu barang atau jasa tersebut. Bahkan hanya untuk memperoleh pengakuan sosial, mengikuti tren atau kepuasan pribadi. Konsumen dalam membeli suatu produk terkadang bukan lagi untuk memenuhi kebutuhan semata, tetapi juga sebagai wujud untuk memuaskan keinginan pribadi. Keinginan tersebut yang seringkali mendorong seseorang untuk membeli barang yang sebenarnya tidak dibutuhkan. Diantara kebutuhan dan keinginan terdapat suatu perbedaan, kebutuhan bersifat naluriah sedangkan keingina nmerupakan kebutuhan buatan, yaitu kebutuhan yang dibentuk oleh lingkungan hidupnya, seperti lingkungan keluarga, atau lingkungan sosial lainnya. Fenomena perilaku konsumtif padakalanganmahasiswa sudah banyak sekali 
ditemui pada masa kini. Masuknya perilaku konsumtif tersebut membawa perubahan pada gaya hidup mahasiswa. Perilaku konsumtif mahasiswa masa kini yang sudah mulai terbiasa dengan berbelanja melalui online shop, lama-lama mulai menjadi suatu kebiasaan yang menjadikan sebuah gaya hidup. Hal ini yang membawa mahasiswa ke dalam tindakan yang mementingkan penampilan luar mereka, harga diri mereka, serta cara mengikuti perkembangan di lingkungan sekitar agar setara. Kebiasaan tersebut menjadikan mahasiswa sulit untuk bersikap rasional, yang pada mulanya mahasiswa diharapkan mampu bertindak rasional dalam menyikapi perkembangan yang ada, menjadika nmahasiswa tidak lagi berorientasi pada masa depan, tetapi justru berorientasi pada gaya hidup yang mereka jalani sekarang. Berdasarkan pra penelitian bahwa mahasiswa FEB UMPRI menunjukkan perilaku konsumtifnya dengan melakukan pembelian melalui online shop. Hal ini dapat dilihat pada tabel berikut di bawah ini:

\begin{tabular}{|c|c|c|c|c|c|c|}
\hline \multirow[b]{2}{*}{$\begin{array}{c}\text { Ang } \\
\text { katan }\end{array}$} & \multirow{2}{*}{$\begin{array}{c}\text { Jumlah } \\
\text { Maha } \\
\text { siswa }\end{array}$} & \multicolumn{5}{|c|}{ Perilaku Konsumtif } \\
\hline & & Laki- & Perem & \multicolumn{2}{|c|}{ Jenis Produk } & $\begin{array}{l}\text { Jumlah } \\
\text { Barang }\end{array}$ \\
\hline \multirow{7}{*}{2016} & \multirow{7}{*}{130} & \multirow{7}{*}{$2,3 \%$} & \multirow{7}{*}{$\begin{array}{c}23,7 \\
\%\end{array}$} & \multirow{3}{*}{$\begin{array}{l}\text { Fas } \\
\text { hion }\end{array}$} & 1. Baju & 565 \\
\hline & & & & & 2.Jilbab & 545 \\
\hline & & & & & 3. Tas & 265 \\
\hline & & & & \multirow{3}{*}{$\begin{array}{c}\text { Kos } \\
\text { metik }\end{array}$} & 1.Lipstik & 260 \\
\hline & & & & & 2. Bedak & 167 \\
\hline & & & & & 3.Skincare & 259 \\
\hline & & & & \multicolumn{2}{|c|}{ Jumlah } & 2.061 \\
\hline
\end{tabular}

Berdasarkan pada tabel di atas, dapat dilihat bahwa jumlah total keseluruhan untuk mahasiswa angkatan 2016 berjumlah 130 orang. Selama, laki-laki yang berperilaku konsumtif sebanyak $2.3 \%$ sedangkan perempuan sebanyak 23,7 \%. Produk online shop yang menyebabkan para mahasiswa berperilaku konsumtif yaitu produk fashion dan kosmetik. Produk fashion terdiri dari baju dengan jumlah barang yang di beli sebanyak 565, jilbab 545, dan tas 265. Dengan presentase untuk baju sebanyak $27,4 \%$, jilbab $26,4 \%$, dan tas $12,8 \%$. Sedangkan produk kosmetik terdiri dari lipstik dengan jumlah barang yang di beli sebanyak 260, bedak 167, dan skincare 249 . Dengan presentase untuk lipstik sebanyak 12,7 $\%$, bedak $8,1 \%$, dan skincare $12,6 \%$

Para perempuan, lebih cenderung berperilaku konsumtif dibandingkan dengan laki-laki. Hal ini diduga karena perempuan lebih gemar berbelanja melalui online shop. Jenis produk yang paling seringdibelanjakan oleh perempuan adalah produk fashion dan kosmetik. Kebanyakan dari perempuan melakukan belanja online karena mengikuti tren jaman sekarang, tersedianyaberagam model yang bisa dipilih sesuka hati, dan lebih mudah dalam melakukan transaksi. Hal ini yang menyebabkan penulis tertarik untuk mengungkapkan masalah dari perilaku konsumtif mahasiswa FEB UMPRI yang dikaitkan dengan pembelian melalui online shop. Online shop merupakan salah satu bentuk pemasaran interaktif yang telahmenjadi tren berbelanja pada kalangan mahasiswa. Banyak mahasiswa yang beranggapan bahwa berbelanja di online shop relatif mudah tidak perlu pergi keluar rumah, hanya bermodalkan smartphone dan aplikasi saja maka barang yang diphutuhthan bisa lebih mudah untuk didapatkan.

\section{B. Rumusan Masalah}

Berdasarkan latar belakang masalah yang telaht ${ }^{2}{ }^{4}$ diurail an di atas, maka rumusan masalah pada penelitian ini adalah: Apakah online shop berpingaruh terhadap perilaku konsumtif mahasiswa HEB UMPRI Tahun2019? C. ${ }_{12}^{8,10}$ Tujuan Penelitian

12. Sésuai lengan latar belakang dan rumusan masala yang tertulis, tujuan dari penelitian ini adalah Ingin mengetahui Pengaruh Online Shop Terhadap Perilaku Konsumtif Pada Mahasiswa FEB UMPRI (StudiKasusPadaMahasiswa FEB UMPRI Angkatan 2016)".

\section{BAB II TINJAUAN TEORITIS}

\section{A. Prilaku Konsumtif}

1. Pengertian Perilaku Konsumtif

Pemenuhan kebutuhan memang sangat penting untuk mengantarkan individu pada kehidupan yang selaras dengan lingkungannya. Pada umumnya, setiap orang akan melakukan kegiatan konsumsi dan menyukai terhadap halhal yang bersifat konsumtif. Vinna (2015: 36) mengemukakan bahwa "konsumtif adalah perilaku berkonsumsi yang boros dan 
berlebihan, yang lebih mendahulukan keinginan daripada kebutuhan, serta tidak ada skala prioritas atau dapat diartikan sebagai gaya hidup yang bermewah-mewahan".

Prehati (Vinna, 2015: 37) mengemukakan bahwa "konsumtivisme adalah berkonsumsi dengan tidak lagi atas pilihan yang rasional berdasarkan kebutuhan, tetapi lebih memperturutkan keinginannya". membutuhkan informasi. Beragam informasi ini diperoleh dari berbagai sumber dan salah satunya berasal dari arsip.

Berdasarkan pengertian tersebut, maka yang dimaksud dengan konsumtif merupakan sebuah keinginan untuk menggunakan atau membeli barang-barang yang sebenarnya kurang diperlukan secara berlebihan, tidak memperhatikan skala prioritas, serta tidak ada kegiatan menghasilkan sendiri tetapi hanya memakai dan menghabiskan saja guna mencapai kepuasan yang maksimal di dalam diri seseorang.

\section{Gaya Hidup dan Perilaku Konsumtif} Mahasiswa

Gaya hidup menunjukkan dimana seseorang mengatur kehidupan pribadinya, kehidupan masyarakat, perilaku di depan umum, dan upaya membedakan statusnya dari orang lain. Gaya hidup dapat diekspresikan melalui hal-hal yang dikenakan seseorang, hal-hal yang mereka konsumsi, dan cara mereka bersikap atau berperilaku di hadapan orang lain. Bagong Suyanto (Vinna, 2015: 33) mengemukakan bahwa "gaya hidup mengandung pengertian sebagai cara hidup yang mencakup sekumpulan kebiasaan, pandangan, dan pola-pola respons terhadap hidup, terutama perlengakapan hidup" Gambaran gaya hidup manusia yang diharapkan, terutama pada mahasiswa yang pada dasarnya merupakan sekelompok anak muda yang mengisi waktunya dengan belajar untuk menambah pengetahuan, keterampilan, keahlian, serta mengisi kegiatan mereka dengan berbagai macam kegiatan positif sehingga akan memiliki orientasi masa depan sebagai manusia yang bermanfaat bagi masyarakat dan bangsa.Hal tersebut dapat dipenuhi dengan mengikuti berbagai aktivitas kampus, aktif di kelas ataupun organisasi, dan sebagainya.Mampu berpikir secara rasional dengan perkembangan yang ada, tidak memilih sesuatu hanya karena kepuasan, tetapi juga kebutuhan.Serta tidak gampang tergoda pada pengaruh yang berkembang pada zaman sekarang karena harus tetap fokus pada masa perkuliahannya. Gaya hidup mahasiswa mengarah kepada perilaku konsumtif yang bertujuan untuk meningkatkan suatu prestise. Dahulu mahasiswa tidak terlalu memikirkan urusan penampilan dan gaya hidup. Mereka lebih mementingkan kebutuhan pokok daripada masalah penampilan, tetapi sekarang berbeda keadaannya karena kini urusan penampilan dan gaya hidup mulai menjadi perhatian serius terutama dikalangan mahasiswa.Masuknya perilaku konsumtif pada kalangan mahasiswa, membawa perubahan pada gaya hidup mahasiswa. Wahidah (Bambang, 2018: 4) mengemukakan bahwa "perilaku konsumtif mahasiswa berpengaruh terhadap gaya hidup hedonis mahasiswa. Perilaku konsumtif tersebut membawa perubahan pada gaya hidup mahasiswa. Perilaku konsumtif mahasiswa yang mulai terbiasa, lama kelamaan mulai menjadi suatu kebiasaan yang menjadikan sebuah gaya hidup. Hal ini yang membawa ke dalam tindakan yang mementingkan penampilan luar mereka, harga diri mereka, serta bagaimana mengikuti perkembangan di lingkungan sekitar supaya setara". Mahasiswa yang berperilaku konsumtif, biasanya mahasiswa yang mengikuti mode atau tren di dalam ataupun di luar kampus.Sering pergi ke tempat-tempat yang dapat meningkatkan citra pergaulannya dan sering melakukan kegiatan belanja atau disebut shopping oleh mahasiswa pada umumnya.Produk-produk yang menarik untuk dikonsumsi oleh mahasiswa adalah produk-produk yang dapat mendukung penampilan, dan produk-produk yang dapat memenuhi kepuasan.Mahasiswa yang konsumtif sering membeli produk baru, padahal produk yang lama masih belum rusak atau masih dapat digunakan. Kebiasaan berperilaku konsumtif tersebut menjadikan mahasiswa sulit untuk bersikap rasional, yang pada mulanya mahasiswa diharapkan mampu bertindak rasional dalam menyikapi perkembangan yang ada, menjadikan mahasiswa tidak lagi 
berorientasi pada masa depan, tetapi justru pada gaya hidup yang mereka jalani sekarang.

\section{Faktor-faktor yang Mempengaruhi Perilaku Konsumtif}

Faktor-faktor yang mempengaruhi perilaku konsumtif sangat banyak namun secara umum dapat dibagi menjadi dua yaitu faktor internal dan eksternal. Menurut Engel (Meike, 2016: 111) Faktor-faktor yang mendasari seseorang berperilaku konsumtif antara lain:

a. Faktor internal, terdiri dari motivasi, pengalaman belajar, kepribadian, konsep diri, situasi, dan gaya hidup. Masing-masing diuraikan sebagai berikut:
1) Motivasi
2) Pengalaman belajar
3) Kepribadian
4) Konsep diri
5) Situasi
6) Gaya hidup

b. Faktor eksternal yang mempengaruhi perilaku konsumtif terdiri dari kebudayaan, kelas sosial, kelompok referensi, dan keluarga.Masing-masing diuraikan sebagai berikut:
1) Kebudayaan
2) Kelas sosial
3) Kelompok referensi
4) Keluarga

Keluarga memegang peranan terbesar dan terlama dalam pembentukan sikap dan perilku konsumen. Berbentuk keyakinan dan kebiasaan yang berfungsi langsung untuk menetapkan keputusan perilaku untuk membeli atau menggunakan produk atau jasa tertentu.

\section{Indikator Perilaku Konsumtif}

Definisi perilaku konsumtif amatlah variatif, tetapi pada intinya muara dari pengertian perilaku konsumtif adalah membeli barang tanpa pertimbangan rasional atau bukan atas dasar kebutuhan pokok. Menurut (Lina dan Rosyid (dalam Miranda 2017: 8) indikator perilaku konsumtif diantaranya:

a. Impulsive Buying (Pembelian impulsif) Impulsive buying adalah pembelian yang terjadi ketika konsumen mengalami desakan tiba-tiba, yang biasanya sangat kuat dan menetap untuk membeli sesuatu dengan segara.

b. Pemborosan, Perilaku konsumtif sebagai salah satu perilaku yang suka menghamburhamburkan banyak dana tanpa disadari adanya kebutuhan yang jelas.

c. Pembelian tidak rasional, Suatu perilaku dimana konsumen membeli sesuatu yang dilakukan semata-mata untuk mencari kesenangan, tanpa ada pertimbangan yang rasional.

\section{B. Online Shop}

1. Penertian Online Shop

Istilah online shop atau toko online pasti sudah tidak asing lagi bagi masyarakat, hampir setiap hari masyarakat selalu mendengar istilah yang populer tersebut. Dari segi bahasa, toko online berasal dari dua suku kata, toko dan online. Sarwandi (2016: 4) mengemukakan bahwa "toko berarti sebuah tempat atau bangunan permanen untuk menjual barangbarang (pakaian, makanan, elektronik) dan sebagainya.Sedangkan online adalah sebuah keadaan di saat seseorang terhubung ke dalam suatu jaringan ataupun sistem yang lebih besar.Dari arti dua suku kata tersebut bisa kita tarik sebuah kesimpulan bahwa online shop adalah tempat terjadinya aktivitas perdagangan atau jual beli barang yang terhubung ke dalam suatu jaringan, aktivitas itu juga disebut dengan belanja online". Nurhayati (2017: 10) mengemukakan "online shop atau toko online merupakan sarana atau toko yang menawarkan barang dan jasa lewat internet". Sari (Miranda 2017: 7) mengemukakan "online shop atau belanja online via internet adalah suatu proses pembelian barang atau jasa dari mereka yang menjual melalui internet, atau layanan jual beli secara online tanpa harus bertatap muka dengan penjual atau pihak pembeli secara langsung". Berdasarkan beberapa pengertian tersebut, maka yang di maksud dengan online shop adalah salah satu fasilitas berbelanja di dunia yang disajikan untuk memenuhi kebutuhan manusia melalui internet.Konsumen pada online shop dapat melihat barang-barang yang mereka inginkan baik dalam bentuk gambar berupa foto-foto ataupun video. Biasanya barang-barang yang dijual oleh online shop 
merupakan barang-barang yang limited edition serta belum pernah ada di pasaran. Di online shop proses transaki yang dilakukan tidak jauh berbeda dengan proses transaksi pada toko biasa. Hanya bedanya jika di toko biasa kita di layani oleh manusia, sedangkan di online shop kita dilayani oleh mesin.

\section{Fungsi dan Penggunaan Online Shop}

Online shop merupakan sebuah website yang memiliki fungsi untuk melakukan transaksi penjualan langsung di internet. Transaki pada online shop tersebut menggunakan form atau aplikasi yang dibuat sedemikian rupa pada online shop tersebut. Sarwandi (2016: 5) mengemukakan "penggunaan pada online shop terdiri dari penggunaan online shop bagi kostumer, dan penggunaan online shop bagi pemilik toko".

\section{Aspek Hukum Dalam Bisnis Online}

Banyaknya kemudahan dalam mengakses internet membuat konsumen pada bisnis online meningkat. Beberapa alasannya seperti, praktis, kemudahan sistem pembayaran, efisiensi waktu, dan banyaknya harga promo yang menarik dari pelaku bisnis online. Dengan adanya internet maka kegiatan perdagangan dapat dilakukan secara elektronik, atau yang lebih dikenal dengan istilah electronic-commerce dan disingkat e-commerce. Namun dibalik segala kemudahan dan keuntungan yang ditawarkan, timbul pula kekhawatiran akan tanggung jawab pelaku bisnisonline kepada konsumen $e$ commerce. Deky Pariadi (2018: 652) mengemukakan "e-commerce adalah suatu bentuk perdagangan yang memiliki karakteristik tertentu, dimana perdagangan tidak berbatas nasional, pembelian tidak saling bertemu secara pribadi, dan media yang digunakan adalah internet. Kondisi ini di satu sisi memberikan keuntungan pada pelanggan karena merasa memiliki berbagai pilihan untuk memperoleh barang dan jasa, namun di sisi lain pelanggaran hak dalam hal ini terhadap konsumen dengan mudah terjadi karena karakteristik yg spesifik dari e-commerce". Oleh karena itu, perlindungan hukum sangat dibutuhkan untuk melindungi pelanggan yang menggunakan transaksi $e$ -
commerce.Keberadaan e-commerce dalam Undang-Undang perdagangan tersebut dirasa sangat penting, melihat potensi serta pertumbuhan bisnis online di tanah air. Deky Pariadi (2018: 654) Berdasarkan hal tersebut, maka akan sangat penting melihat konsumen sebagai subjek yang sangat erat kaitannya dengan bisnis online sehingga diperlukan perlindungan bagi para konsumen.

\section{Indikator Online Shop}

Online shop atau toko online merupakan sarana pembelian yang dilakukan via internet sebagai media pemasaran dengan menggunakan website sebagai katalog. Menurut Nurhayati (2017: 17) indikatoronline shop diantaranya:

a. Efisiensi Waktu, Perkembangan internet menjadikan aktivitas belanja menjadi jauh lebih nyaman, karenabelanja online telah mengambil bentuk yang relatif memudahkan bagibeberapa penggunanya.Belanja online bagi sebagian konsumen memilikiwarna baru untuk memenuhi kebutuhan. Keuntungan paling produktif daribelanja online adalah memungkinkan seseorang untukmengakses banyak item dari merek yang berbeda dan efisiensi waktu.Menghemat waktu dalam membeli kebutuhan atau berkonsumsi ini dipilih sebagian konsumen dalam memanfaatkan media belanja melaui online shop.

b. Akses yang Mendukung, Online shop menawarkan banyak kemudahan dan keuntungan,konsumen tidak perlu lagi keluar rumah mengeluarkan biaya transportasi dan waktu untuk mendatangi toko yang diminati. Cukup dengan membuka komputer atau laptop dan gadget, menyalakan akses internet dan membuka alamat portal belanja online yang dituju. Pada intinya adalah ketika akses mendukung untuk melakukan suatu hal maka sangat mudah untuk mendapatkan apa yang diinginkan.

c. Sebagai Pemenuhan Kebutuhan, Online shop merupakan salah satu fasilitas berbelanja di dunia yang disajikan untuk memenuhi kebutuhan manusia. Online shopmemberikanwarna sendiri bagi pemenuhan berkonsumsi. Online shop pada kenyataanyajuga memberikan satu nilai yaitu 
nilai eksistensi diri di lingkungan sekitar. Konsumsi mengekpresikan posisi sosial dan identitas seseorang dalam kehidupan sosial masyarakat terjadi karena telah banyaknya cara untukmemenuhi kebutuhan akan suatu nilai yaitu gengsi.

\section{Kerangka Pikir}

Menurut Sugiyono (2018: 129) "kerangka pikir merupakan sintesa tentang hubungan antar variabel yang disusun dari berbagai teori yang telah di deskripsikan". Kerangka pemikiran yang diajukan dalam penelitian ini adalah variabelonline shop, dengan indikator online shop diantaranya: efisiensi waktu, akses yang mendukung, sebagai pemenuhan kebutuhan. Saat ini banyak sekali konsumen yang gemar melakukan belanja online, online shop merupakan bisnis yang sangat berkembang saat ini. Beragam produk menarik yang ditawarkan serta kemudahan dalam memilih barang dan bertransaksi, menjadi beberapa keunggulan online shop. Berbelanja di online shop tidak membuat konsumen bosan bahkan cenderung senang mengkonsumsibarang di online shop, karena di online shop mendapatkan berbagaikeuntungan diantaranya efisiensi waktu dan mendapatkan barang yangupdate. Online shop menjadikan segala sesuatu menjadi terasa mudah dalam berbelanja, terlebih dengan banyaknya akses yang mendukung untu membuka situs online shop tersebut sehingga memudahkan konsumen dalam memenuhi segala kebutuhannya. Tidak menutup kemungkinan bahwa cara berbelanja seperti ini akan membawa konsumen kepada perilaku konsumtif yang cenderung mengeluarkan biaya tinggi untuk memenuhi kebutuhannya. Perilaku konsumtif sendiri merupakan perilaku berkonsumsi yang boros dan berlebihan. Suatu perilaku konsumtif dimulai dengan seringnya melakukan pembelian ataupun menggunakan suatu barang atau jasa yang tidak didasarkan pada faktor kebutuhan dan tidak ada skala prioritas. Kebanyakan konsumen akan berperilaku konsumtif hanya untuk menunjang rasa percaya diri, harga diri, sekedar mengikuti tren yang ada, serta untuk menciptakan rasa kepuasan di dalam dirinya. Sehingga muncul pengaruh antara online shop terhadap perilaku konsumtif yang diakibatkan karena seringnya melakukan pembelian pada online shop tersebut.

\section{BAB III METODOLOGI PENELITIAN}

\section{A. Metode Penelitian}

Metode penelitian merupakan sekumpulan peraturan, kegiatan, dan prosedur yang digunakan oleh pelaku suatu disiplin. Penelitian merupakan suatu penyelidikan yang sistematis untuk meningkatkan sejumlah pengetahuan, juga merupakan suatu usaha yang sistemastis dan terorganisasi untuk menyelidiki masalah tertentu yang memerlukan jawaban. Dalam penelitian ini menggunakan metode penelitian kuantitatif. Menurut Sugiyono (2018: 23) "Metode kuantitatif dapat diartikan sebagai metode penelitian yang berdasarkan pada filsafat positivisme, digunakan untuk meneliti pada populasi atau sampel tertentu, pengumpulan data menggunakan instrumen penelitian, analisis data bersifat kuantitatif atau statistik, dengan tujuan untuk menggambarkan dan menguji hipotesis yang telah ditetapkan"..

\section{B. Definisi Operasional Variabel}

Definisi operasional variabel penelitian merupakan pengertian variabel yang diungkapkan dalam definisi konsep tersebut, secara operasional, secara praktis, secara nyata, dalam objek peneltian. Definisi operasional merupakan suatu penjelasan konsep yang terdapat pada judul penelitian yang diukur jenis dan tingkatnya sehingga variabel-variabel yang diteliti menjadi jelas. Penelitian ini menggunakan variabel bebas yaitu Online Shop dan variabel terikat yaitu Perilaku Konsumtif.

\section{Metode Pengumpulan Data}

Metode pengumpulan data merupakan faktor penting dalam keberhasulan suatu penelitian. Hal ini berkaitan dengan bagaimana cara mengumpulkan data, siapa sumbernya dan apa alat yang digunakan. Dalam penelitian ini data yang digunakan adalah data primer, data primer dalam penelitian ini yaitu data berupa opini, sikap, pengalaman, atau karakteristik dari seseorang atau kelompok yang menjadi objek penelitian. Adapun teknik pengumpulan data yang digunakan oleh peneliti adalah sebagai berikut: 


\section{Dokumentasi}

Menurut Sugiyono (2015: 202) "metode dokumentasi adalah menyelidiki benda-benda tertulis seperti buku-buku, majalah, dokumen, peraturan-peraturan, dan sebagainya". Dokumentasi dalam penelitian ini diperlukan untuk mengatahui profil FEB UMPRI, struktur organisasi FEB UMPRI, visi, misi serta hal-hal yang berkaitan dengan penelitian ini.

\section{Observasi}

Menurut Sugiyono (2018: 377) "observasi sebagai teknik pengumpulan data mempunyai ciri yang spesifik bila dibandingkan dengan teknik yang lain, yaitu wawancara dan kuesioner". Dalam metode ini peneliti melakukan pengamatan langsung terhadap perilaku konsumtif mahasiswa pada pembelian produk online shop.

\section{Kuesioner}

Menurut Sugiyono (2018: 230) "Kuesioner merupakan teknik pengumpulan data yang dilakukan dengan cara pemberian seperangkat pertanyaan atau pernyataan tertulis kepada responden untuk dijawabnya". Dalam penelitian ini kuisioner dirancang dengan sifat tertutup untuk mengetahui pengaruh online shop terhadap perilaku konsumtif pada mahasiswa FEB UMPRI.

\section{Instrumen Penelitian}

Instrumen penelitian merupakan semua alat yang digunakan untuk mengumpulkan, memeriksa, menyelidiki suatu masalah, atau mengolah dan menyajikan data-data secara sistematis secara objektif dengan tujuan untuk memecahkan suatu persoalan. Instrumen yang digunakan peneliti untuk mendapatkan data pada penelitian ini yaitu pedoman dokumentasi untuk mengetahui profil FEB UMPRI, visi dan misi FEB UMPRI, struktur organisasi FEB UMPRI (dituangkan pada Bab IV) dan pedoman observasi untuk melihat dan mengamati perilaku konsumtif mahasiswa pada pembelian produk online shop (dituangkan pada Bab I) Penelitian ini menggunakan angket dalam mengumpulkan data. Data dikumpulkan dalam bentuk skala Likert, yaitu "skala ini digunakan untuk mengukur sikap, pendapat, dan persepsi seseorang atau sekelompok orang tentang fenomena sosial yang terjadi, hal ini sudah ditetapkan secara spesifik oleh peneliti" (Sugiyono, 2018: 168). Angket disusun dengan pertanyaan-pertanyaan sesuai variabel yang diteliti. Selanjutnya menurut Sugiyono (2018: 168) menjelaskan bahwa jawaban setiap item instrumen yang menggunakan skala likert mempunyai gradasi dari sangat positif sampai sangat negatif yang berupa kata-kata. Instrumen disusun berdasarkan indikator-indikator dari online shop dan perilaku konsumtif yang telah dilakukan oleh mahasiswa yang akan diwakili oleh pertanyaan ataupun pernyataan dengan alternatif jawaban yang direspon dalam bentuk skala likert, yang diungkapkan melalui katakata.

\section{E. Populasi, Sampel dan Teknik Pengambilan Sampel}

1. Populasi

Populasi adalah wilayah generalisasi yang Sugiyono (2018: 148) mengemukakan "populasi adalah wilayah generalisasi yang terdiri dari objek atau subjek yang mempunyai kuantitas dan karakteristik tertentu yang ditetapkan oleh peneliti untuk dipelajari dan diambil kesimpulannya". Adapun yang menjadi populasi dalam penelitian ini adalah mahasiswa FEB UMPRI angkatan 2016 yang berjumlah 130 mahasiswa.

\section{Sampel}

Sugiyono (2018: 149) mengemukakan "sampel adalah bagian dari jumlah dan karakteristik yang dimiliki oleh populasi tersebut". Bila populasi besar dan peneliti tidak mungkin mempelajari semua yang ada di populasi, misal karena keterbatasan dana, tenaga dan waktu, maka peneliti dapat menggunakan sampel yang diambil dari populasi itu. Apa yang dipelajari dari sampel itu, kesimpulannya akan diberlakukan untuk populasi. Untuk itu sampel harus betul-betul representative (mewakili). Mengenai besarnya sampel Suharsimi Arikunto (2017 : 210) mengemukakan didalam pengambilan sampel apabila subyeknya kurang dari 100 maka diambil semua sehingga penelitian merupakan penelitian populasi.Selanjutnya jika jumlah subyek nya besar atau lebih dari 100, dapat diambil antara $10 \%-15 \%$ atau $20 \%$ - 25\% atau lebih. "Untuk populasi 130, dengan taraf kesalahan 20\% 
jumlah sampel = 26". Maka peneliti memutuskan untuk mengambil sampel dengan taraf kesalahan 20\% dengan jumlah sampel sebanyak 26 mahasiswa FEB UMPRI angkatan 2016.

\section{Teknik Sampling}

Untuk menentukan sampel yang digunakan pada penelitian, terdapat beberapa teknik sampling yang digunakan. Dalam penelitian ini, peneliti menggunakan teknik probability sampling. Sugiyono (2018: 151) "probability sampling adalah teknik pengambilan sampel yang memberikan peluang yang sama bagi setiap unsur (anggota) populasi untuk dipilih menjadi sampel". Dalam penelitian ini peniliti menggunakan jenis teknik sampling simple random sampling. Menurut Sugiyono (2018: 152) "dikatakan simple (sederhana) karena pengambilan anggota sampel dari populasi dilakukan secara acak tanpa memperhatikan strata yang ada dalam populasi itu”.

\section{F. Metode Analisis Data}

Dalam hal ini kuesioner sebagai instrumen penelitian sebelumnya perlu dilakukan uji coba untuk mengetahui apakah kuesioner tersebut mampu dipahami atau tidak, agar nantinya data tersebut memenuhi syarat valid dan reliable. Teknik uji coba instrumen penelitian dilakukan kepada 10 mahasiswa FEB UMPRI di luar sampel di dalam populasi dan selanjutnya dilakukan uji validitas dan reliabilitas. Setelah dikatakan valid dan reliabel maka dilanjutkan dengan menyebar kuesioner kepada 26 mahasiswa di FEB UMPRI.

\section{Uji Validitas}

Uji validitas digunakan untuk menunjukkan kevalidan butir pernyataan sehingga dapat digunakan sebagai alat ukur penelitian. Menurut Sugiyono (2018: 203) "Valid berarti instrumen tersebut dapat digunakan untuk mengukur apa yang seharusnya diukur". Untuk mengukur uji validitas instrumen menggunakan rumus korelasi product moment dibantu dengan menggunakan aplikasi SPSS. Menurut Sugiyono (2018: 286) rumus korelasi product moment sebagai berikut:

$$
r=\frac{n \sum x y-\left(\sum x\right)(\Sigma y)}{\sqrt{\left[n \sum x^{2}-\left(\sum x\right)^{2}\right]\left[n \sum y^{2}-\left(\sum y\right)^{2}\right.}}
$$

Keterangan:

$\mathrm{r}=$ nilai validasi

$\mathrm{n}=$ banyaknya jumlah sampel yang akan diuji

$\mathrm{x}=$ pertanyaan ke- $\mathrm{t}$

$\mathrm{y}=$ jumlah dari seluruh pertanyaan

Kriteria putusan

Jika $r_{x y-h i t u n g}>r_{x y-t a b e l}$ maka kuesioner valid Jika $r_{x y-\text { hitung }}<\mathrm{r}_{x y-t a b e l}$ maka kuesioner tidak valid

\section{Uji Reliabilitas}

Uji reliabilitas digunakan untuk mengukur sejauh mana alat ukur dapat dipercaya atau diandalkan. Uji reliabilitas menggunakan rumus korelasi Cronbach's Alpha (Wiratna Sujarweni, 2015: 110)

Rumus:

$\mathrm{r}=\left(\frac{k}{k-1}\right)\left(1-\frac{\sum \sigma_{b}^{2}}{\sigma_{t}^{2}}\right)$

Keterangan:

$\mathrm{r} \quad=$ koefisien reliabilitas

$k$ = banyaknya butir pertanyaan

$\sigma_{t}^{2}=$ total varians

$\sum \sigma_{b}^{2}=$ total varians butir

Menurut Wiratna Sujarweni (2015: 110) jika nilai alpha $>0,60$ maka dinyatakan reliabel.

\section{Analisis Regresi Linier Sederhana}

Alat statistik yang digunakan untuk mengetahui pengaruh antar variabel adalah regresi linier. Dalam penelitian ini, karena hanya memiliki satu variabel bebas dan satu variabel terikat, maka alat statistik yang digunakan adalah regresi linier sederhana karena sesuai dengan tujuan penelitian. Menurut Sugiyono (2018: 293) rumus regresi linier sederhana yaitu:

$$
Y^{\prime}=a+b X
$$

Keterangan:

$\mathrm{Y}=$ Nilai yang diprediksikan

$\mathrm{a}=$ Konstanta

$\mathrm{b}=$ Koefisien regresi

$\mathrm{X}=$ Nilai koefisien variabel bebas

\section{Pengujian Hipotesis}

Pengujian hipotesis regresi sederhana dibagi menjadi dua yaitu pengujian koefisien regresi sederhana dan pengujian tingkat signifikansi. 
Pernyataan hipotesis untuk koefisien regresi sederhana yaitu:

$\mathrm{H}_{0}: \mathrm{b}=0 \rightarrow$ Online shop berpengaruh terhadap Perilaku Konsumtif Pada Mahasiswa FEB UMPRI

$\mathrm{H}_{1}: \mathrm{b} \neq 0 \rightarrow$ Online shop tidak berpengaruh terhadap Perilaku Konsumtif Pada Mahasiswa FEB UMPRI

Pengujian tingkat signifikansi pada alpha 5\% (0.05) menggunakan uji t. Menurut Sugiyono (2013: 255) rumusnya adalah sebagai berikut:

$t=\frac{r \sqrt{n-2}}{\sqrt{1-r^{2}}}$

Keterangan:

$\mathrm{t}=$ Nilai $\mathrm{t}_{\text {hitung }}$

$\mathrm{r}=$ Nilai korelasi

$\mathrm{n}=$ Jumlah data

Kriteria pengujian:

1) $\mathrm{H}_{0}$ ditolak jika $\mathrm{t}$ statistik $<0,05$ atau $t_{\text {hitung }}>t_{\text {tabel }}$

2) $\mathrm{H}_{0}$ diterima jika $t$ statistic $>0.05$ atau $\mathrm{t}_{\text {hitung }}<\mathrm{t}_{\text {tabel }}$ Nilai $\mathrm{t}_{\text {tabel }}$ di dapat dari $\mathrm{df}=$ $\mathrm{n}-\mathrm{k}$

Keterangan:

$\mathrm{n}=$ jumlah observasi

$\mathrm{k}=$ variabel penelitian

\section{Keofisien Determinasi}

Koefisien determinasi (R2) pada penelitian ini untuk mengetahui besaran pengaruh Online shop terhadap Perilaku Konsumtif Pada Mahasiswa FEB UMPRI. Rumus yang digunakan untuk mencari nilai koefisien determinasi yaitu:

$\mathrm{Kd}=\mathrm{R}^{2} \times 100 \%$

Keterangan:

$\mathrm{Kd}=$ Koefisien determinasi

$\mathrm{R}^{2}=$ Koefisien korelasi (Sugiyono, 2015: 231)

\section{BAB IV HASIL DAN PEMBAHASAN}

\section{A. Sejarah Singkat}

Sekolah Tinggi Ilmu Ekonomi (STIE) Muhammadiyah Pringsewu Lampung berdiri pada tanggal 8 Agustus 1996 dengan Akte Ny. Erny Tjandra Sasmita, S.H., Nomor 53. Sekolah Tinggi Ilmu Ekonomi (STIE) Muhammadiyah Pringsewu merupakan salah satu perguruan tinggi yang berada di Pringsewu dengan beralamatkan di Jalan makam K.H. Ghalib no. 112 Pringsewu. Sekolah Tinggi Ilmu Ekonomi (STIE) Muhammadiyah Pringsewu berada dibawah naungan Yayasan Muhammadiyah, dengan memiliki satu program studi yaitu manajemen dan tiga konsentrasi yaitu manajemen pemasaran, manajemen sumberdaya manusia, dan manajemen keuangan. Pada tanggal 29 Juli 2019 Sekolah Tinggi Ilmu Ekonomi (STIE) Muhammadiyah Pringsewu bergambung dengna Perguruan tinggi lainnya yakni STKIP dan STIKes Muhammadiyah Pringsewu Lampung bergabung menjadi Universitas Muhammadiyah Pringsewu (UMPRI) Lampung.

\section{B. Pengumpulan Dan Penyajian Data}

1. Uji Validitas dan Realibilitas Try out a. Uji Validitas

Uji validitas dimaksudkan untuk mengetahui apakah instrumen dapat dikatakan valid atau tidak valid sehingga dapat digunakan sebagai alat ukur penelitian. Dalam penelitian ini uji validitas dilakukan dengan cara melakukan uji coba try out 10 mahasiswa Fakultas Ekonomi dan Bisnis Universitas Muhammadiyah Pringsewu diluar sampel. Selanjutnya dianalisis menggunakan uji validitas item dengan menggunakan rumus korelasi product moment. Melalui dasar penentuan $r$ tabel dengan $\mathrm{N}=10$ yaitu 0,632. Berikut hasil uji validitas item pernyataan Online Shop dan Prilaku Konsumtif Mahasiswa. Berdasarkan perhitungan validitas membuktikan bahwa dari 14 item pernyataan kuesioner yang diuji cobakan dapat dinyatakan valid, hal tersebut dikarenakan nilai r-hitung pada setiap nomor item pernyataan lebih besar (>) daripada $r$-tabel 0.632 (nilai $r$-tabel untuk $\mathrm{n} /$ sampel $=10$ ).

\section{b. Uji Realibilitas Try out}

Uji realibilitas dimaksudkan untuk mengukur sejauh mana alat ukur yang dipakai dapat dipercaya untuk membahas permasalahan Pengaruh Online Shop Terhadap Perilaku Konsumtif Mahasiswa FEB UMPRI (Studi Kasus Pada Mahasiswa FEB UMPRI Angkatan 2016). Pengujian realibilitas menggunakan rumus korelasi Cronbach Alpha. Hasil 
perhitungan reliabilitas, dapat dinilai Cronbach Alpha pada variabel Online Shop dan Perilaku Konsumtif. artinya sudah memenuhi syarat reliabel karena nilai Cronbach Alpha> 0.6. Setelah dilakukan uji Try out, maka dapat disimpulkan bahwa kuisioner dapat dinyatakan valid dan reliabel sehingga kuisioner ini bisa diteruskan untuk pengambilan dan penelitian yang disebarkan kepada responden.

Setelah dilakukan uji validitas dan realibilitas maka sudah dianggap sah bahwa kuisioner ini dapat di sebarkan ke responden resmi.

\section{Analisis Deskriptif}

Analisis deskriptif merupakan penjelasan dari data hasil penyebaran kuesioner tentang Pengaruh Online Shop Terhadap Perilaku Konsumtif Mahasiswa FEB UMPRI (Studi Kasus Pada Mahasiswa FEB UMPRI Angkatan 2016). Selain itu, digunakan untuk menganalisis data dengan cara mendeskripsikan atau menggambarkan data yang telah terkumpul dan dijelaskan dengan pendekatan teori Online Shop dan Prilaku Konsumtif mahasiswa.

a. Deskripsi Online Shop

Hasil penghitungan menjelaskan bahwa Online Shoppada Mahasiswa FEB UMPRI Angkatan 2016 yang paling dominan masuk dalam kategori tinggi. Hal tersebut terlihat dari frekuensi pernyataan pada variabel Online Shop sebesar 65,39\% atau sebanyak 17 responden menganggap Online Shop FEB UMPRI adalah Baik dan 34,61\% atau sebanyak 9 responden menganggap Online Shop FEB UMPRI dalam kategori sedang.

b. DeskripsiPerilaku Konsumtif

Hasil penghitungan menjelaskan bahwa Perilaku Konsumtif Mahasiswa Fakultas Ekonomi dan Bisnis Universitas Muhammadiyah Pringsewu angkatan 2016 yang paling dominan masuk dalam kategori tinggi. Hal tersebut terlihat dari frekuensi pernyataan sebesar 76,93\% atau sebanyak 20 RespondenMahasiswa Fakultas Ekonomi dan Bisnis Universitas Muhammadiyah Pringsewu angkatan 2016 memandang yang dimiliki masih tinggi dan $23,07 \%$ atau sebanyak 6 responden menganggap Perilaku Konsumtif Mahasiswa Fakultas Ekonomi dan Bisnis Universitas Muhammadiyah
Pringsewuangkatan 2016 dalam kategori sedang.

\section{Analis Data}

Untuk menjawab hipotesis dan melihat besaran Pengaruh media Online Shop terhadap Prilaku Konsumtif Mahasiswa Fakultas Ekonomi dan Bisnis Universitas Muhammadiyah Pringsewu angkatan 2016, maka digunakan alat statistik regresi linear sederhana. Berikut hasil perhitungan dengan menggunakan regresi sederhana yang didasari dari hasil penyebaran kuesioner kepada 26 mahasiswa Mahasiswa Fakultas Ekonomi dan Bisnis Universitas Muhammadiyah Pringsewu angkatan 2016. Berdasarkan penghitungan regresi Sederhana diperoleh persamaan sebagai berikut:

$$
\mathrm{Y}=2,032+0,724 \mathrm{X}
$$

Persamaan di atas merupakan bentuk persamaan Pengaruh Online Shop Terhadap Perilaku KonsumtifMahasiswa Fakultas Ekonomi dan Bisnis Universitas Muhammadiyah Pringsewu. Berdasarkan persamaan tersebut, dapat diketahui bahwa:

1. Nilai konstanta sebesar 2,032 . Nilai tersebut berarti apabila terdapat variabel Online Shop (X) nilainya adalah 0 maka Perilaku Konsumtif (Y) nilainya adalah 2,032.

2. Koefisien regresi Online Shop (X) sebesar 0,724 . Nilai tersebut berarti apabila nilai variabel Online Shop (X) naik, maka Perilaku Konsumtif (Y) akan meningkat sebesar 0,724 . Koefisien bernilai positif yang berarti Online shop berpengaruh terhadap Perilaku Konsumtif Pada Mahasiswa Fakultas Ekonomi dan Bisnis Universitas Muhammadiyah Pringsewu Angakatan 2016.

3. Berdasarkan perhitungan di atas didapat hasil sebagai berikut Nilai t-hitungOnline Shop (X) sebesar $4,173>t$-tabel $(0,684)$, yang berarti terdapat pengaruh Online Shop (X) terhadap Perilaku Konsumtif (Y) Pada Mahasiswa Fakultas Ekonomi dan Bisnis Universitas Muhammadiyah Pringsewu Angakatan 2016, dengan demikian $\mathrm{H}_{1}$ diterima dan $\mathrm{H}_{0}$ ditolak.

4. Hasil perhitungan regresi linear Sederhana didapat nilai $r$-square sebesar 0,473 sehingga dapat disimpulkan bahwa Perilaku 
Konsumtif mahasiswa Fakultas Ekonomi dan Bisnis Universitas Muhammadiyah Pringsewu mampu dijelaskan sebesar 47,3\% oleh variabel Online Shop padamahasiswa Fakultas Ekonomi dan Bisnis Universitas Muhammadiyah Pringsewu angkatan 2016. Dengan kata lain, variabel Online Shopmemberikan kontribusi sebesar 47,3\% terhadap Perilaku Konsumtif Mahasiswa pada Fakultas Ekonomi dan Bisnis Universitas Muhammadiyah Pringsewudan sisanya sebesar $52,7 \%$ dijelaskan atau dipengaruhi faktor lain yang tidak diidentifikasi dalam penelitian ini.

\section{E. Pembahasan Hasil Penelitian}

Tujuan dari penilitian ini ingin melihat Pengaruh Online Shop Terhadap Perilaku Konsumtif Mahasiswa Fakultas Ekonomi dan Bisnis Universitas Muhammadiyah Pringsewu angkatan 2016. Dari hasil pengujian data didapatkan bentuk pengaruh variabel Online Shop terhadap Perilaku KonsumtifMahasiswa Fakultas Ekonomi dan Bisnis Universitas Muhammadiyah Pringsewu dengan arah positif. Dengan demikian dapat dijelaskan bahwa jika variabel Online Shop di Fakultas Ekonomi dan Bisnis Universitas Muhammadiyah Pringsewuditingkatkan maka akan diikuti dengan meningkatnya Perilaku Konsumtif Mahasiswa Fakultas Ekonomi dan Bisnis Universitas Muhammadiyah Pringsewu. Pada nilai $\mathrm{t}$-hitungOnline Shop > t-tabel, yang berarti terdapat pengaruh Online Shop terhadap Perilaku Konsumtif Mahasiswa Fakultas Ekonomi dan Bisnis Universitas Muhammadiyah Pringsewu.

\section{BAB V KESIMPULAN DAN LUARAN}

\section{A. Kesimpulan}

Kesimpulan dari hasil penelitian pengaruh Online Shop terhadap Perilaku Konsumtif Mahasiswa Fakultas Ekonomi dan Bisnis Universitas Muhammadiyah Pringsewu adalah sebagi berikut:

1. Berdasarkan hasil penghitungan dengan menggunakan analisis regresi linier sederhana, ternyata hipotesis yang diajukandapat diterima yaitu Online Shop berpengaruh terhadap Perilaku
KonsumtifPada Mahasiswa Fakultas Ekonomi dan Bisnis Universitas Muhammadiyah Pringsewu Angakatan 2016. Hal ini dibuktikan dengan Nilai thitung Online Shop (X) sebesar 4,173>t-tabel $(0,684)$, dengan demikian $\mathrm{H}_{1}$ diterima dan $\mathrm{H}_{0}$ ditolak.

2. Hasil perhitungan regresi linear Sederhana didapat nilai $r$-square sebesar 0,473 sehingga dapat disimpulkan bahwa Perilaku Konsumtifmahasiswa Fakultas Ekonomi dan Bisnis Universitas Muhammadiyah Pringsewu mampu dijelaskan sebesar 47,3\% oleh variabel Online Shop. Dengan kata lain, variabel Online Shop memberikan kontribusi sebesar 47,3\% terhadap Perilaku Konsumtifmahasiswa Fakultas Ekonomi dan Bisnis Universitas Muhammadiyah Pringsewu dan sisanya sebesar 52,7\% dijelaskan atau dipengaruhi faktor lain yang tidak diidentifikasi dalam penelitian ini.

\section{B. Luaran}

Setelah dilakukan pembahasan terhadap masalah, selanjutnya penulis memberikan beberapa saran antara lain:

1. Online Shop lebih optimal dalam meningkatkan selera mahasiswa Fakultas Ekonomi dan Bisnis Universitas Muhammadiyah Pringsewu.

2. Online Shop lebih memudahkan mahasiswa Fakultas Ekonomi dan Bisnis Universitas Muhammadiyah Pringsewu dalam berbelanja hanya dengan mengakses internet melalui laptop maupun gadget.

3. Memberikan edukasi kepada mahasiswa Fakultas Ekonomi dan Bisnis Universitas Muhammadiyah Pringsewu bahwa Perilaku konsumtif terjadi karena seringnya menghamburkan banyak dana tanpa adanya kebutuhan yang jelas.

\section{DAFTAR PUSTAKA}

Arikunto, S. (2017).Pengembangan Instrumen Penelitian dan Penilaian Program. Yogyakarta: Pustaka Pelajar.

Bambang Setia Wibowo. (2018). Pengaruh Instagram Online Store, Konformitas dan Iklan Televisi Terhadap Perilaku Konsumtif Serta Dampaknya Terhadap 
Gaya Hidup Hedonis Mahasiswa. Jurnal Bisnis Teori dan Implementasi, vol. 9 no. 1

Deky Pariadi. (2018). Pengawasan ECommerce Dalam Undang-Undang Perdagangan Dan Undang-Undang Perlindungan Konsumen, Jurnal Hukum \& Pembangunan Vol.48 No.3

Meike Yalinda, Totok S. (2016). Faktor yang Mendorong Perilaku Konsumtif Siswa SMA di Surabaya. Jurnal Kajian Moral dan Pendidikan, Vol. 01 No. 04

Nurhayati. (2017). Belanja "Online" Sebagai Cara Belanja Dikalangan Mahasiswa. Aceh Anthropological Journal Volume 1 No. 2

Sarwandi. (2016). Toko Online Modern Dengan Opencart, Jakarta: PT. Elex Media Komputindo.

Sofia Miranda. (2017). Pengaruh Instagram Sebagai Media Online Shopping Fashion Terhadap Perilaku Konsumtif Mahasiswi Fakultas Ilmu Sosial Dan Ilmu Politik Universitas Riau. JOM FISIP, Vol. 4 No. 1

Sri Yuniarti, Vinna. (2015). Perilaku Konsumen Teori dan Praktik, Bandung: CV Pustaka Setia.

Sugiyono. (2018). Metode Penelitian Manajemen, Bandung: Alfabeta.

(2015). Metodologi Penelitian Kuantitatif dan Kualitatif R \& D, Bandung: Alfabeta.

(2013). Metode Penelitian Bisnis, Bandung: Alfabeta

Sujarweni, wiratna v. (2015). Metodologi Penelitian Bisnis \& Ekonomi, Yogyakarta: Pustakabarupress. 